\title{
On The Path of Pir Sultan? Engagement with Authority in the Modern Alevi Movement
}

\section{Caroline Tee}

The Alevis are an Islamic minority group in Turkey, whose precise numbers are difficult to ascertain (Shankland 2003). Their interpretation of Islam is generally considered >heterodox « by the Sunni Muslim majority, and it has never been officially recognized by the Turkish state. The Alevi tradition or Alevilik ${ }^{1}$ is a syncretistic one, combining Sufi mysticism, elements of pre-Islamic shamanism, and the central conceits of Shi'i Islam - namely, adulation of Imam Ali and mourning for the martyrs of the Battle of Karbala (Birge 1994; Melikoff 1998). Traditionally, the Alevis lived in isolated, rural communities, with a concentration in the mountainous regions of central and eastern Anatolia (Andrews 2002). In the middle of the last century, many Alevis began to migrate to Istanbul and other big cities in the west, as well as to Europe, and today the community is largely an urban and diasporic one.

The term >Alevi Movement $<$ refers to the activities underway in the Alevi community over approximately the last 20 years, aimed at reviving and reformulating its Alevi identity and traditions (Kehl-Bodrogi 1988; Vorhoff 1995). Religious, cultural and socio-political elements are all playing an important part in the movement, and its major goal is official recognition of Alevilik by the Turkish state. ${ }^{2}$ There is a closely associated movement amongst the sizeable Alevi diaspora in

1 I use the Turkish term Alevilik to refer to the Alevi tradition throughout this paper. This is because it conveys a sense of its holistic nature, made up of religious, cultural and historical elements. The English terms >Alevism ` and >Aleviness ‘ are, I believe, relatively limited by their individual emphasis on the political and cultural aspects of the tradition respectively.

2 The AKP government instigated an initiative called the Alevi Açlımı (Alevi Opening) at the start of its second term in office in 2007. In its concluding report in the spring of 2011, the basic demands of the Alevis (recognition of cemevis as official places of worship; abolition of compulsory religious education in secondary schools; opening of a museum of remembrance at the Madımak Hotel in Sivas) remained unmet. See Köşe (2010). 
Western Europe (namely Germany), which faces, and is influenced by, different political and societal influences (Massicard 2005; Sökefeld 2008). In this paper, I focus on the Turkish Alevi Movement, and the ways in which it is negotiating with authoritarian discourses on national and religious identity in Turkey, as well as with institutions of religious and political power.

Protest and the subversion of religious and political authority are traits often associated with the Alevis. The iconic image of the subversive folk poet Pir Sultan Abdal, raising his saz aloft in defiance, is easily recognizable in Turkey as an Alevi symbol. This paper explores the legitimacy of this stereotype of rebellion. It presents an ethnographic exploration of how one Alevi group, the Derviş Cemal Ocak from Erzincan, is reformulating its Alevi identity by actively engaging with certain aspects of authoritarian discourses on ethnicity and religion in modern Turkey - namely, Turkishness and self-identification as Muslim. It situates this group within the wider, national framework of the modern Alevi Movement, and the different approaches to engagement with authority represented within it. ${ }^{3}$

\section{Minorities in the Turkish Republic: Çağaptay's ıZones Of Turkishnessı}

A helpful framework for understanding the issue of engagement with authority in the Alevi Movement is provided by Soner Çağaptay's identification of three zzones of Turkishness « in the Kemalist construction of Republican national identity (Çağaptay 2006). Çağaptay delineates an >inner zone of Turkishness`, which is defined by ethnic Turkishness and religious identification with Sunni Islam. The majority of the population belongs within this 'zone`, wherein they have close relations with the state and easy recourse to engagement in the public sphere. In the second $>$ zone $<$, in an approach inspired by the Ottoman millet system, are those whose religious identification is the same, i. e., Sunni Muslim, but whose ethnicity is non-Turkish (i. e., the Kurdish Sunni population). In the third and outer >zoner, and experiencing the most comprehensive sense of exclusion, are non-Muslims living within the territorial parameters of the modern Turkish nation-state (i. e., Jews and Christians). Çağaptay states that:

3 A full ethnographic study of the Derviş Cemal Ocak, from which selected material is presented here, has been published by the author elsewhere. See > Holy Lineages, Migration and Reformulation of Alevi Tradition: A Study of the Derviş Cemal Ocak from Erzincan « in British Journal of Middle Eastern Studies, December 2010, 37, 3, 335-392. 
... today, in the scheme of concentric circles of Turkishness, the further away a group is from the center, the more unaccommodating is the state toward it. Only when a group is located in the innermost, ethnic zone, does it enjoy close proximity to the state. Moreover, while groups from the religious layer are expected to move into the inner ethnic core, groups from the territorial zone are strictly confined to the hostile margins of society. (Çă̆aptay 2006: 160)

The location of the Alevis within this framework is variable, and contingent on a number of complex and inter-related factors. First of all, the Alevi population is made up of both Kurdish (Kurmanji and Zaza ${ }^{4}$ ) and Turkish-speaking populations. Whilst excluded from the >inner zone because of their non-identification with Sunni Islam, the Turkish Alevis nonetheless come closer to qualifying than their Kurdish counterparts on account of their Turkish ethno-linguistic affiliation. The Kurdish Alevis, by contrast, are comprehensively relegated to the second zone because of both their non-Turkish ethnicity and their distance from Sunni Islam.

Furthermore, the Alevi community is fragmented over the issue of Alevilik's rightful inclusion within the parameters of Islam. This constitutes one of the major debates within the modern movement, wherein certain Alevi groups locate the origins of the Alevi tradition in early Islamic history, yet others identify preIslamic and Anatolian influences as the major determinants of its development. There is therefore potential for different Alevi groups to move either inwardly, towards the >inner zone of Islamic (albeit not Sunni Islamic) religious identity, or outwardly, towards the >territorial zone « inhabited by relatively disenfranchised non-Muslims.

\section{Modes of Engagement in the Alevi Movement Nationally}

There are two broad ideological trends visible within the Alevi Movement in Turkey today, each represented by a major institutional voice and each apparently negotiating its relationship with the metaphorical >inner zone of Turkishness $<$ in rather a different way. The first group is, broadly speaking, represented by the Istanbul-based Cem Vakf1, which was founded by İzzettin Doğan, a professor of international law, in 1995. It presents Alevilik as a religious tradition situated firmly within the parameters of Islam and based on Turkish culture. It appeals to the religious authority of the Qur'an as well as the cultural heritage of Turkic saints in its articulation of >Alevi Islam $\prec$. This is explained on the Cem Vakf website:

4 Zaza is a northwest Iranian language. See Paul (1998). 
The birth of the Alevi understanding of Islam was inspired by the views of those saintly possessors of wisdom, the best interpreters of the Koran, Hoca Ahmet Yesevi, Ebul Vefa, Hacı Bektaş Veli, Yunus Emre, Mevlana, Pir Sultan Abdal and the [other] Anatolian saints. Islam came to Anatolia through this interpretation. ${ }^{5}$

The Cem Vakfı is broadly conciliatory in its approach to official authority, and is open to dialogue with the Directorate of Religious Affairs, within which it seeks representation and provision for Alevilik as a valid Islamic tradition alongside the Sunni one. Its approach to achieving recognition is based on an appeal to the powerful twin criteria of national identity and citizenship, namely Turkish ethnicity and Islamic religious identity, and as such its trajectory is an inward one, seeking proximity to the >inner zone`.

The Alevi-Bektashi Federation, or ABF, is another major voice within the Alevi Movement today that represents a noticeably less conciliatory and more overtly politicized discourse. Founded in Ankara in 2002, it is an umbrella organization listing 31 affiliated Alevi groups. Like the Cem Vakf1, the ABF seeks official recognition of Alevilik by the Turkish state, but rather than engage with the Directorate of Religious Affairs, it demands its abolition on the grounds that its existence violates the principles of secularism. It generally refutes the interpretation of Alevilik that roots it in Islam, and espouses a thesis of origins as a pre-Islamic, and sometimes proto-socialist tradition. Ali Balkız, president of the ABF until March 2011, explained Alevilik in the following way in an interview with Radikal newspaper in 2002:

Alevilik is a communal phenomenon that was shaped in Anatolia from a variety of beliefs, ways of life, philosophies and cultures that originated in Central Asia, Khorasan, Mesopotamia and the Middle East. It is an independent way of interpreting and understanding nature, society and God. ${ }^{6}$

It is possible that Alevis from follower lineages are attracted to the ABF more than those of sacred (leader) lineages, ${ }^{7}$ and it has a considerable membership amongst Kurdish and Zaza Alevis who often stress their Kurdishness and Zazaness as well as their Alevi identity. The ABF represents an Alevilik that is less concerned with

5 http://www.aleviislamdinhizmetleri.com/alevilik_nedir.asp. Accessed o1-o8-12. English translation by the author.

6 Article by Muray Aksoy in Radikal newspaper, 22 February 2002. English translation by the author.

7 The Alevi community is organized according to sacred (dede) and non-sacred lineages, which are decided by birth. On the religious organization of Alevi society, see Shankland (2003) and Yaman (2004). 
engagement with central authority, which plays down the origins of the tradition in Turkish culture, and is reluctant to situate itself within the parameters of Islam. Accordingly, its trajectory is an outward facing one, wherein proximity to the sinner zone of Turkishness is not sought, and accordingly it occupies a place closer to what Çağaptay calls the >hostile margins of society<.

\section{Ethnographic Case-Study: The Derviş Cemal Ocak}

This paper presents an ethnographic approach to understanding the internal dynamics of the Alevi Movement, and the factors influencing its different approaches to engagement with the Turkish state. It explores the case of the Derviş Cemal Ocak, an Alevi group from Erzincan that is currently engaged in reviving and reformulating its Alevi identity and traditions. Broadly speaking, this group is aligning itself with the Cem Vakfı discourse on Alevilik and identifying itself as part of a religious tradition based in Islam with a strong sense of Turkish cultural origins. The foci of its revival activities are reinstated religious ritual (namely, the central scem < ceremony), restoration of sacred sites, and collation and codification of its oral history and narrative of origins. Revival activities began in around 2000, and have gathered pace considerably since 2010. They are administered from Istanbul, where many members of the ocak have lived since the middle of the last century. The information that I present here is taken from two years of ethnographic fieldwork amongst the Derviş Cemal Ocak at various locations in Turkey between July 2009 and June 2011.

\section{History of the Derviş Cemal Ocak}

The term ocak denotes, in Alevilik, an extended family of religious leaders who claim descent down a sacred lineage (van Bruinessen 2000). These leaders are known as $\operatorname{dede}(s)$. A network of ocaks constituted the backbone of traditional, Anatolian Alevi society, which was organized according to the affiliation of nonsacred, follower lineages to particular dedes. The Derviş Cemal Ocak takes its name from a $15^{\text {th }}$ century Anatolian holy man, Seyyid Derviş Cemal, and its members trace their descent through him to a $13^{\text {th }}$ century companion of Haci Bektaş Veli, called Seyyid Cemal Sultan, and before him to the Prophet Muhammad.

Until the onset of mass migration, which began in around 1960 and continued until the 1990s, the ocak was concentrated around its spiritual and geographical center, the village of Zurun - renamed Çayıryazı in the Republican era but still referred to within the ocak by its Ottoman name. Zurun is located high in the 
Figure 1 Map showing the distribution of the Tanyeri villages with Derviş Cemal dede residents in south-eastern Erzincan.

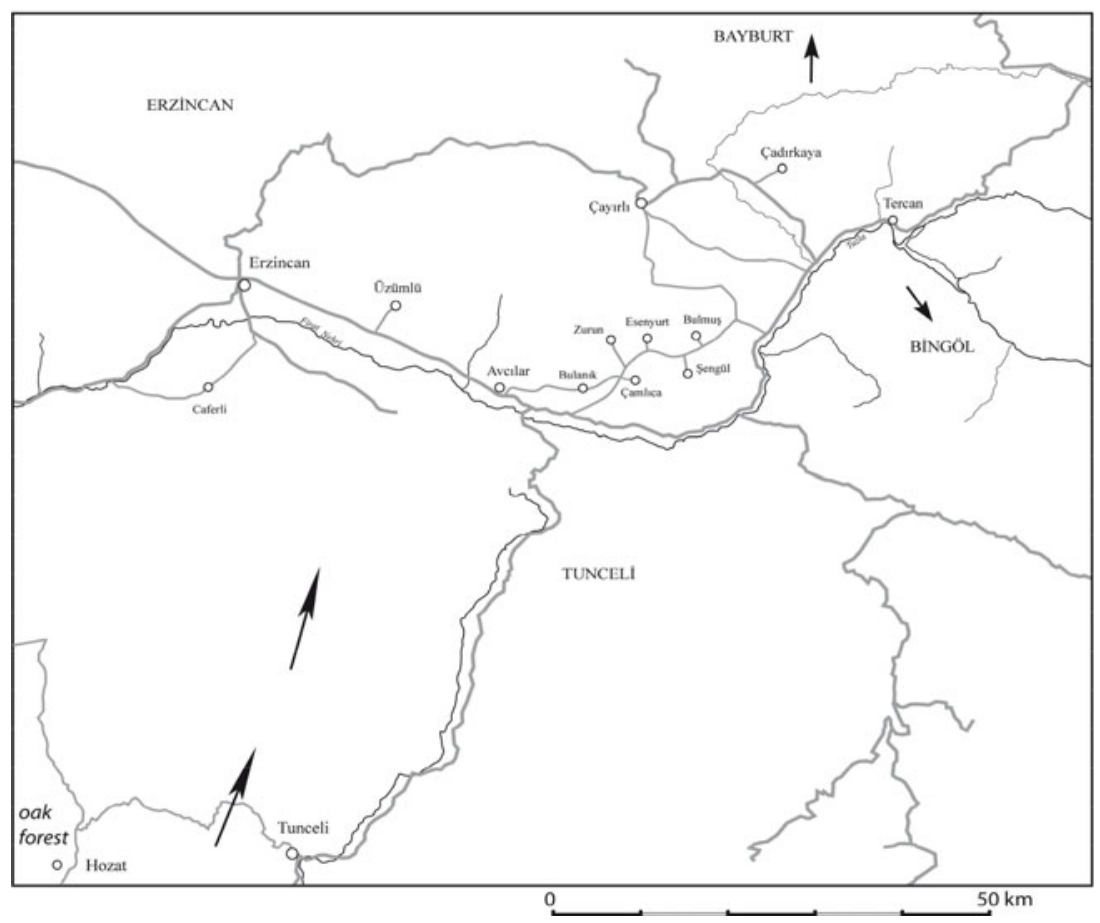

remote mountains of south-eastern Erzincan, near to the modern-day border with Tunceli. ${ }^{8}$ It is at the centre of a cluster of six villages, known as the Tanyeri villages, which were all traditionally inhabited by Zaza-speaking, Derviş Cemal dedes. Zurun is the so-called serçeşmer, or source, of the ocak, a term which demarcates it as the place where charismatic spiritual authority is located. Since its settlement, probably in around the $16^{\text {th }}$ century, it has been the home of the Şeyh Dede, the head of a hierarchy of dedes within the ocak, believed to be a direct descendant of Derviş Cemal and possessor of `keramet`, or the ability to perform miraculous acts. The last great Şeyh Dede in popular memory was İbrahim Demir, to whom acts of keramet are attributed and who died in 1936.

8 Tunceli is the new name that was given to Dersim in the 1930s, at the time of major civil unrest in the region. 
The ocak seems to have been fairly typical of many eastern Alevi groups during the rural era, in terms of its independence and the apparently extreme degree of geographical as well as social isolation (Yaman 2006). Many >lead dedes × from ocaks in the Dersim region would turn to one another for the provision of spiritual oversight and accountability that is essential to all Sufi traditions. Although an Alevi dede is considered a religious leader, he is also considered a disciple of the Alevi Way ( $y o l$ ), and therefore in need of the oversight of a spiritual master (pir) himself. In the case of the Derviş Cemal Ocak, there does not seem to have been a bi-lateral local arrangement with other ocaks; rather, the ocak apparently maintained some kind of institutional link with the Bektaşi convent in Nevşehir. This is perhaps not surprising given that the ocak traces its decent to one of the companions of Hacı Bektaş Veli who was sent out from that convent. It is, however, unusual for an eastern Alevi group to have had links with the Bektaşis, whose influence was generally stronger amongst the Turkish Alevis in the west of Anatolia (van Bruinessen 1997; Karakaya-Stump 2012).

\section{Migration}

Religious life in the ocak suffered enormously during the era of mass rural to urban migration. Alevilik could not, and did not, transfer easily from its small, rural village locations to the relative anonymity of large, urban centers (Shankland 2003). Like the rest of the Alevi community nationally, in the mid- $20^{\text {th }}$ century the practice of the cem ceremony and other associated aspects of religious life in the ocak fell into decline. Members were scattered through migration primarily to Istanbul (Kartal and Bağcılar), and Germany (Frankfurt), but there are also Derviş Cemal people in Izmir, Antalya and other parts of western Turkey as well as in other Western European countries. According to the broad trend amongst the Alevis in the 1960s and 7os, many Derviş Cemal people were politically active within the leftist movement during that era.

\section{Revival in The Ocak}

A turning point came for the ocak in 2000, when a group of individuals, now residing in Germany, decided to restore the tekke of the Şeyh Dede in Zurun. The tekke, which had been derelict for decades, was rebuilt as a modern cemevi. The movement to revive and reformulate ocak tradition and identity has gathered pace in the last two years. In February 2010, members of the ocak living in Istanbul organized a cem ceremony in Bağclar Cemevi to which they invited all members of 
Figure 2 Derviş Cemal Ocak cem ceremony at Bağcılar Cemevi, Istanbul, February 2010. (Photograph by the author)

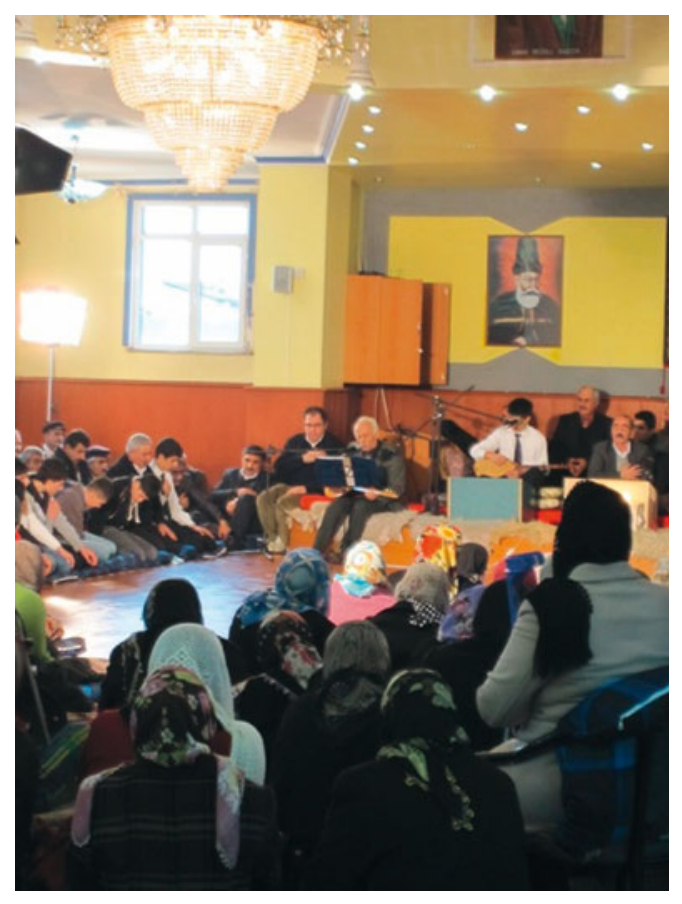

the ocak to attend. The cem was well attended, by around 500 people, and it appeared on the national Alevi TV channel, Cem TV, a few weeks later.

The cem revealed a popular desire for the ocak to re-group and reclaim it traditions and practices, and as such an official association (dernek) was established shortly afterwards. Its title was > The Association for Solidarity, Proliferation and Protection of Seyyid Cemal Sultan Culture «; in early 2012, it was upgraded to the status of vakıf (pious trust). This trust is currently directing the ocak's revival activities. Besides the resurrected cem ritual (the February cem in Istanbul has since become an annual event), it has also been overseeing the restoration of certain sacred sites. It has also been collating and informally publishing the oral histories and miracle narratives that are associated with these sacred sites through official ocak websites and a modest ocak magazine.

Its interest in the religious and cultural aspects of its Alevi heritage and identity align the activities of the Derviş Cemal Ocak with the interpretation of Ale- 
vilik espoused by the Cem Vakfi. Its members are largely choosing to identify themselves as >Alevi Muslim «, in line with the Cem Vakfi's definition of Alevilik as a Turkish interpretation of Islam. This relatively conciliatory approach to defining itself today is interesting, given the ocak's origins in the restive Tunceli region, and its potential for experiencing a certain marginalization on account of being a Zaza rather than a Turkish speaking group. Neither of these features would seem to preclude easy engagement with mainstream discourses surrounding religion, ethnicity and citizenship in Turkey today.

\section{Dede Heritage as religious Legitimization}

The ocak is, however, finding scope for engagement and, I suggest, it is doing this by revisiting and emphasizing its dede identity. The narrative of sacred descent makes it possible for the ocak to claim both Turkish ethnicity and religious legitimacy within the boundaries of Islam. This narrative is based on a common interpretation of Anatolian Alevi history that begins with the migration of Hacı Bektaş Veli from the Central Asian region of Khorasan in the $13^{\text {th }}$ century (Yaman 2004). Hacı Bektaş was accompanied on this journey into Anatolia by a number of Turkic holy men, known as the Horasan Erenleri, or >enlightened ones from Khorasan These holy men reputedly intermarried with descendants of the Prophet Muhammad through Imam Ali in Khorasan, thus combining their Turkic ethnicity with the charismatic sanctity of Muhammad's lineage.

The Derviş Cemal Ocak trace their descent back to Seyyid Cemal Sultan, one of the Khorasan Erenleri, whom oral ocak history tells us to have been one of the closest companions of Hacı Bektaş and resident with him at the convent in Nevşehir. The story of Seyyid Cemal Sultan forms one of the cornerstones in revived ocak identity, partly through the re-telling of his life and special association with Hacı Bektaş Veli, and partly through a focus on redeveloping the site surrounding his tomb. The story of Seyyid Cemal Sultan was told to me by various dedes within the ocak. It also appears in the Velayetname of Hacı Bektaş:

Sultan Hacı Bektaş Veli had three hundred and sixty companions who served in his presence during his lifetime. When he died, each of these companions left for the place to which the Sultan (Hacı Bektaş) had sent them. Of all the companions, the Sultan loved Seyyid Cemal Sultan the most [....]. The Sultan commanded: »My Cemal, after I have died, buy a donkey and leave here. The place where the wolves eat your donkey is the place which we are giving you for your home. Later on you will have a son, and he will walk across water. « After the Sultan died (c.1271/2), Seyyid Cemal Sultan bought a donkey and set off. By and by, he came to Altıntaş. It was an unbelievably beautiful 
place - extremely verdant and well-watered, with lush meadows and a river. Seyyid Cemal liked the place very much, and wanted to rest a while. He sent his donkey off to the river, and laid down for a nap. When he woke up, he saw that the donkey had been eaten by wolves. Straight away, he remembered the words which the Sultan had spoken, and so he settled there, got married and had a son. He called his son Asildoğan. (Author's translation)

The association with Hacı Bektaş is important to the ocak, for it affords it crucial legitimization and a claim to sanctity. The village of Altıntaş that is referred to in the narrative is near the modern day town of Döğer, in the western province of Afyonkarahisar. It is unusual for an ocak from the Dersim region to have a history in western Anatolia.

This tomb did not play an important part in the religious life of the ocak during the rural era, and was rediscovered only about three years ago. There is currently an extensive ocak project underway to renovate and develop the site. Building work began in the summer of 2011 to structurally overhaul the existing buildings, (which include the tomb itself, as well as an outhouse), and also to build a cemevi,

Figure 3 The tomb of Seyyid Cemal Sultan at Döğer, Afyon. (Photograph by the author)

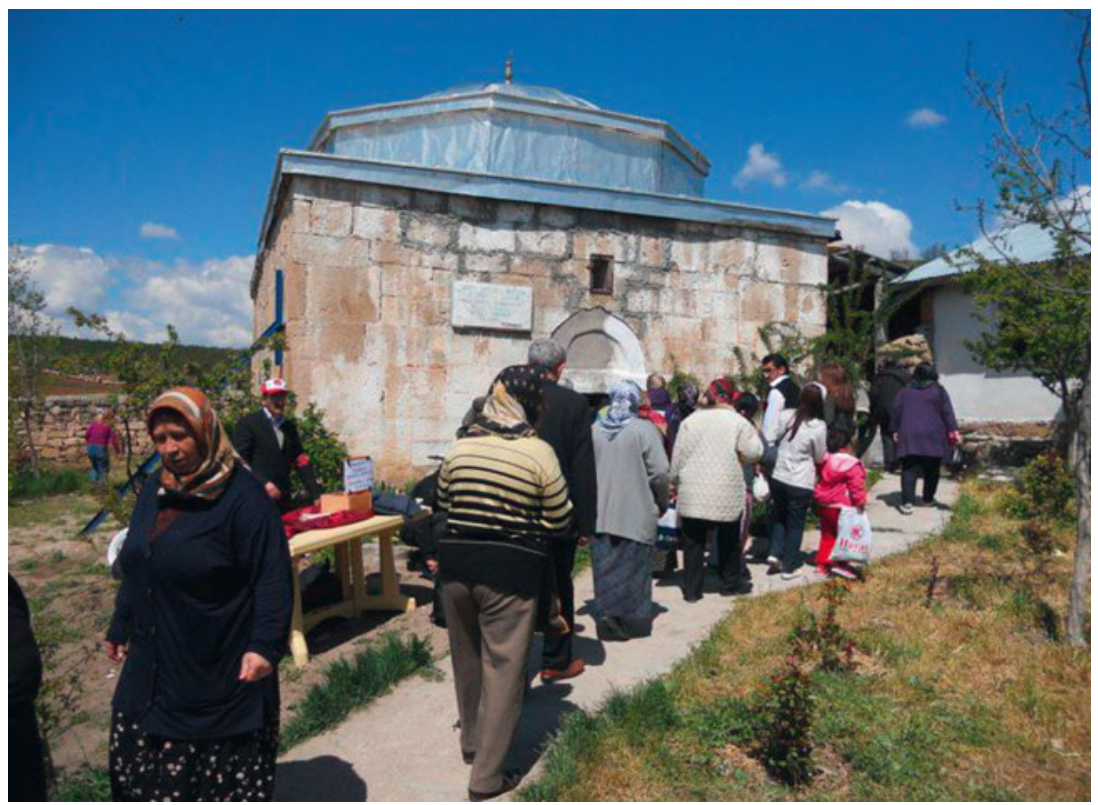


a guesthouse and an aşevi (kitchen) for the preparation of sacrificial food when the ocak is gathered together there. The tomb in Afyon has also become the site of an annual ocak festival, which will shortly be returned to in more detail.

Seyyid Cemal had a son called Asildoğan, whose life and miraculous exploits also feature in oral ocak history. Asildoğan is said to have travelled extensively around the Sea of Marmara, and is reputed to have demonstrated keramet by walking across the water at Çanakkale. This is, again, a shortened version of the story as it appears on an ocak website:

Seyyid Asildoğan left the Altıntaş (Döğer) region to spread the message to the people, and headed to Çardak, opposite Gallipoli. He wanted to cross over to Gallipoli. That region was Greek in those days, and the Greek boatmen there would not give Seyyid Asildoğan a boat. Neither would they take him across in one of their own boats. The boatmen left the shore and set out for the open sea. After a while, they looked back and saw that Seyyid Asildoğan, whom they had left on the shore, was coming towards them, walking on the water. They realised that this man was senlightened (ermiş), and they immediately turned back to the shore, took Seyyid Asildoğan into their boat and delivered him over to Gallipoli on the other side. Just as the Sultan (Hacı Bektaş) had told his father he would, Seyyid Asildoğan demonstrated keramet by walking on water. (Author's translation)

\section{\Kerametı (Miracle) Stories}

This story is one of many oral narratives that are being revisited and written down by members of the ocak today that features keramet, or miraculous activity, being performed by a holy ancestor. These narratives often culminate with the ancestor providing irrefutable proof of his supernatural powers to a previously skeptical audience - in this case, Greek Christians, but more commonly, Sunni Muslims. The ancestor is often then exonerated of unjust charges that have been brought against him. Michael Gilsenan, anthropologist of the Middle East, has observed the tendency of such miracle stories in the wider Islamic region to fit this pattern, noting that, "(they) break the normal pattern of things and force opponents to admit their error. The notion of challenge and contest is very strong." (Gilsenan 1973).

Emphasizing these narratives of sacred descent from the Prophet Muhammad and of keramet demonstrate, on the one hand, a desire within the Derviş Cemal Ocak for religious legitimization according to Islam. The reason their ancestors were able to perform such apparently miraculous feats is that they are allegedly heirs to the charismatic authority of the Prophet of Islam himself. This brings the 
ocak into a central position in terms of its ability and willingness to engage with the Sunni majority, on the grounds that they share a common Islamic foundation. In contrast, other Alevi groups, and especially those affiliated to the ABF, prefer to maintain a peripheral position in this sense, and to avoid entering into religious negotiation on these terms altogether.

On the other hand, however, the notions of challenge and contest that are central to these keramet stories indicate a degree of subversion. Whilst there is a common idiom of Islam in this reading of Alevi history, it is used mainly to show how (Sunni) outsiders have misunderstood and mistreated the Alevis. The desire for the recognition of Alevilik, which accompanies the telling of these stories today, is founded on this centuries-long narrative of injustice and discrimination. The voice of protest in them is therefore quite important.

\section{Sacred Sites in Ocak Revival}

Asildoğan's grave is believed to be in the town of Simav, near Beyce in the province of Kütahya. It was not until two generations after Asildoğan that Derviş Cemal, for whom the ocak is named, lived. He is said to have migrated from Muğla, in western Anatolia, to the town of Hozat in Dersim in the $15^{\text {th }}$ century. Derviş Cemal did not settle in Hozat, but reportedly fled to Erzincan under persecution from Sul$\tan$ Selim I in the early $16^{\text {th }}$ century. The grave of Derviş Cemal is near Zurun, outside the village of Bulmuş. Despite being located in the centre of the Derviş Cemal homeland, the grave of Derviş Cemal does not seem to have featured prominently until recently, and when I was there in 2009 and 2010, many members even struggled to identify where it was. Although it has recently been covered by a new concrete edifice, the site is still much smaller and considerably more remote than the tomb complex of Seyyid Cemal in Afyon. It is clearly the Afyon site that attracts the most attention and provides a geographical focus for the ocak in its revival activity. It is playing host to a newly instated, annual ocak festival, called the Seyyid Cemal Sultan Anma Töreni, or memorial ceremony. The first festival took place in May 2009 and has happened every year since. When I attended it, in May 2010, there were upwards of 500 people there, most of whom had come from Istanbul.

The festival was dominated by religious and cultural elements. It was, first and foremost, an organized siyaret , or small-scale pilgrimage, to the tomb of Seyyid Cemal Sultan. Most people who attended visited the tomb to offer prayers there. There was also a large kurban, or sacrifice, carried out. Sheep were slaughtered, and a communal meal of sacrificial food was prepared and consumed together. The sacrifice would normally take place alongside a cem ceremony, and indeed, the ocak plans to run a cem at the annual festival as soon as the building work is com- 
Figure 4 Seyyid Cemal Sultan Memorial Ceremony, May 2010. (Photograph by the author)

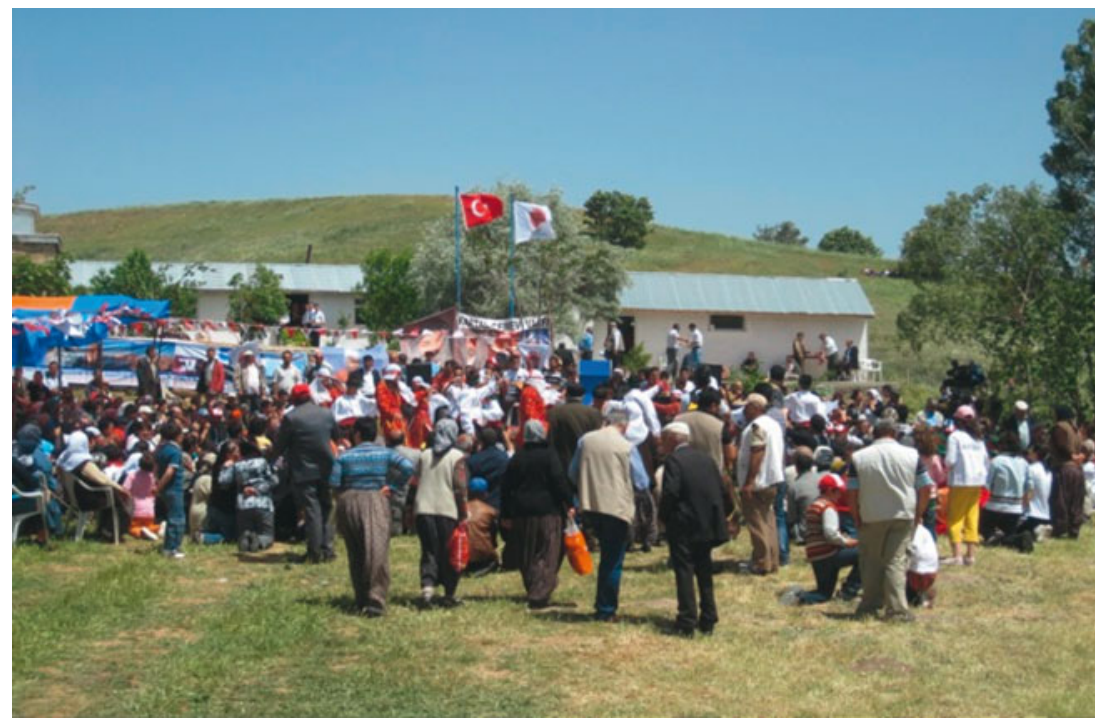

pleted and there is a suitable space to do so. The cultural aspects of the festival included the singing of Alevi poetry to saz accompaniment by various aşıks, and the performance of the semah. This was carried out by a youth-group from a cemevi in Istanbul who, as is common within the Alevi movement today, take regular evening classes in dancing the semah. For the performance, they wore the traditional Anatolian folk costume often adopted by such groups, since the semah began to be performed publically in the Alevi revival.

There was evidence of a muted and conciliatory attitude towards political authority. The AKP Minster for Culture, Ertuğrul Günay, came from Ankara and made a brief speech about the historical significance of the tomb site and of the cultural value of the festival, which was largely warmly received by participants. Furthermore, the committee of the ocak association had sought - and gained - the co-operation of the local AKP council both in order to hold the festival, and to approve its plans for the redevelopment of the site. Like most Alevis, individuals in the ocak generally support the $\mathrm{CHP}$ and dislike the religiously conservative nature of the governing AKP. They do, however, seem comfortable engaging and negotiating with the AKP when it is deemed necessary to do so.

The tomb of Seyyid Cemal Sultan has become a central motif in the renewal of Derviş Cemal Ocak identity and corporate life in the 21st century. It is attracting 
a degree of interest that has meant the focus of contemporary ocak activity, rather than being in the Erzincan homeland of Zurun, is instead hundreds of miles away in western Turkey. The appeal of the Afyon site can be understood on a number of different levels: firstly, it emphasizes the ocak's direct association with Hacı Bektaş Veli and the western Bektaşis, something which brings it to a relatively >central< position both religiously and politically. (The Bektaşi Order represents in many ways a more conciliatory face of Alevilik that has been historically much closer to central political power). This association distances the Derviş Cemal Ocak from the comparatively rebellious and independent Kurdish Alevi tribes in the east. Secondly, the narrative of Seyyid Cemal Sultan that is represented by the tomb site embeds the origins of the Derviş Cemal Ocak in Turkish history and culture. This situates the group centrally in terms of its claim to ethnic identification with the aforementioned sinner zone of Turkishness . The third and fourth factors concern the geography of the site: it is located in a relatively $>$ safe $<$ part of the country in the southwest, rather than in proximity to the still-restive Dersim region; and finally, it is practically much more accessible to members of the ocak, now living in large numbers in Istanbul, than the relatively distant Erzincan homeland.

\section{Concluding Remarks}

In sum, the case of the Derviş Cemal Ocak presents us with evidence that some Alevis are finding ground for engagement with powerful, semi-official narratives surrounding religious and cultural identity in Turkey today. The ocak still rejects and subverts the Sunni interpretation of Islam and, in that sense, defines itself according to the age-old juxtaposition of the 'Sunni other . It is also, however, perhaps expedient to emphasize those aspects of its corporate identity that offer it the potential for engagement with that >other . Accordingly, its actions challenge the popular stereotype of rebellion associated with the Dersim Alevis. For the Derviş Cemal Ocak, it is largely its dede heritage that is making this possible, giving it recourse to negotiate proximity to Çağaptay's >inner zone of Turkishness $<$ by stressing its Turkish cultural identity and Islamic religious affiliation. The prospects for Alevis of Kurdish or Zaza ethnicity, who are also of follower lineage, to approach similarly central ground, seem relatively bleak. Excluded from the so-called >holy trinity of Sunni-Muslim-Turk ( Kaya 2010), it seems likely that they will continue to seek Alevilik's official recognition from a relatively peripheral place in Turkish society. Whether or not either approach will prove fruitful remains to be seen. 


\section{References}

Andrews, Peter A. (with Rüdiger Benninghaus). Ethnic Groups in the Republic of Turkey. Wiesbaden: L. Reichert, 2002.

Birge, John Kingsley. The Bektashi Order of Dervishes. London: Luzac Oriental, 1994.

Çağaptay, Soner. Islam, Secularism and Nationalism in modern Turkey: Who is a Turk? London: Routledge, 2006.

Gilsenan, Michael. Saint and Sufi in Modern Egypt: an essay in the sociology of religion. Oxford: Clarendon, 1973.

Karakaya-Stump, Ayfer. 2010. »Documents and Buyruk Manuscripts in the Private Archives of Alevi Dede Families: An Overview «, British Journal of Middle Eastern Studies. 37,3: 273-286.

Kaya, Ayhan and Harmanyeri, Ece. 2010. »Tolerance and Cultural Diversity Discourses in Turkey«. Accept Pluralism $7^{\text {th }}$ Framework Programme Project. San Domenico di Fiesole, Italy: European University Institute, Robert Schuman Center for Advanced Studies.

Kehl-Bodrogi, Krisztina. Die Kizilbas/Aleviten: Untersuchungen über eine esoterische Glaubensgemeinschaft in Anatolien. Berlin: Klaus Schwarz, 1988.

Köse, Talha. 2010. > Alevi Opening and the Democratization Initiative in Turkey «. SETA Policy Report No. 3 (March 2010).

Massicard, Elise. L'Autre Turquie. Paris: Presses Universitaires de France, 2005.

Mélikoff, Irène. Hadji Bektach: Un Mythe et ses Avatars. Leiden: Brill, 1998.

Paul, L. Zazaki: Grammatik und Versuch einer Dialektologie. Wiesbaden: L. Reichert, 1988.

Shankland, David. The Alevis in Turkey: The Emergence of a Secular Islamic Tradition. London, New York: Routledge Curzon, 2003.

Sökefeld, Martin. Struggling for Recognition: The Alevi Movement in Germany and in Transnational Space. New York, Oxford: Berghahn, 2008.

Van Bruinessen, Martin. Mullas, Sufis and Heretics: The Role of Religion in Kurdish Society. Istanbul: İsis, 2000.

Van Bruinessen, Martin. » Aslını İnkar Eden Haramzadedir! « The Debate on the Ethnic Identity of the Kurdish Alevis`, in Syncretistic Religious Communities in the Near East, edited by Kehl-Bodrogi, et al. Leiden: Brill, 1997.

Vorhoff, Karin. Zwischen Glaube, Nation und neuer Gemeinschaft: Alevitische Identität in der Türkei. Berlin: Klaus Schwarz Verlag, 1995.

Yaman, Ali. Alevilikte Dedelik ve Ocaklar. Istanbul: Barış Matbaası, 2004.

Yaman, Ali. Kızılbaş Alevi Ocakları. Ankara: Elips, 2006.

Open Access. This chapter is distributed under the terms of the Creative Commons Attribution Noncommercial License, which permits any noncommercial use, distribution, and reproduction in any medium, provided the original author(s) and source are credited. 